\title{
Community Mental Health Services and Research Clinic (KP2KJM) Muhammadiyah University of East Kalimantan Mukhripah Damaiyanti ${ }^{1 *}$, Ghozali $\mathrm{MH}^{2}$, Dwi Rahmah Fitriani ${ }^{1}$, Ramdhany Ismahmudi ${ }^{1}$, Yuliani Winarti ${ }^{2}$ \\ ${ }^{1}$ Department of Psychiatry, Faculty of Nursing, Muhammadiyah University of East Kalimantan, Samarinda, Indonesia \\ ${ }^{2}$ Department of Public Health, Faculty of Public Health, Muhammadiyah University of East Kalimantan, Samarinda, Indonesia
}

Submitted: October 16 ${ }^{\text {th }}$ 2018; Revised: June $4^{\text {th }} 2021$; Accepted: November 27 2021

$\begin{array}{ll}\text { Keywords: } & \text { Abstract Mental health disorders will interfere the overall health of a person, } \\ \text { Client } & \text { so families and communities needs to increase the knowledge of families and } \\ \text { Clinic } & \text { community members in determining the condition of mental disorders, as well } \\ \text { Mental health } & \text { as how to intervene and implement mental disorder management. There are } \\ \text { Service } & \text { some services for it, namely the mental health consultation service program, } \\ & \text { modality therapy, client home visits, health education for the community, and } \\ & \text { mental health cadres. The results in the change of percentage level of family } \\ \text { knowledge after given the actions are as follows: moderate category increases } & \text { from } 35.7 \% \text { to } 46.03 \% \text {, the good category increases from } 23.02 \% \text { to } 33.86 \%, \\ & \text { while the poor category decreases from } 41.27 \% \text { to only } 20.11 \% \text {. It is currently } \\ \text { preparing to collaborate with doctors and Healthcare and Social Security } \\ \text { Agency (Badan Penyelenggara Jaminan Sosial or BPJS) as the first-level health } \\ \text { facilities and pharmacy services that are open to the public. Based on the results } \\ \text { of research conducted, it shows that the program implemented can increase } \\ \text { knowledge of mental health services in the community. }\end{array}$

\section{INTRODUCTION}

Mental health is an inseparable part of health in general, as well as a fundamental part of human growth and development, both physically, intellectually, and emotionally, in order to be optimal and harmonious (Law No. 36, 2009). Mental health disorders, unlike other diseases, do not appear immediately, but rather accumulate over time and cannot be adapted or solved (Varcarolis et al. 2006). Mental disorders will interfere overall health so it is important for nurses to detect, strengthen, support, and promote health with their clients (Fortinash \& Worret, 2004; Kessler, 2005).

According to the data by the World Health Organization (WHO), mental disorder issue has become a significant concern all over the world. WHO estimates that there are around 450 million people worldwide who suffer from mental disorders (Yosep, 2013). The Basic Health Research (2018) explains that the prevalence of mental disorders in Indonesia is $7.0 \%$.
In East Kalimantan Province, the prevalence of mental disorder is $4.0 \%$ in Samarinda City, $7.6 \%$ in Paser, $6.0 \%$ in West Kutai, $4.8 \%$ in Kutai Kartanegara, $11.4 \%$ in East Kutai, $8.1 \%$ in Penajam, $11.3 \%$ in Balikpapan, and $3.8 \%$ in Bontang City, with $5.5 \%$ of males and $8.3 \%$ of females.

The impact of mental disorders is strongly affected by the signs and symptoms experienced. A person with mental disorder requires extended hospitalization, causes disruption in their family, high treatment expenses incurred by patients and the government, and instills fear in others (Mamnuah \& Nurjannah, 2019). Family members that suffer from mental disorders will also be a burden for the family, both objective and subjective. The patient's behaviour, role performance, support needs, and financial expenditures incurred by the family are the objective burdens. Meanwhile, the subjective burden is related to the feeling of being burdened, such as grief, guilt,

ISSN 2460-9447 (print), ISSN 2541-5883 (online)

*Corresponding author: Mukhripah Damaiyanti

Department of Psychiatry, Faculty of Nursing, Muhammadiyah University of East Kalimantan, Jl. Ir. H. Juanda No. 15 Samarinda, East Kalimantan, Indonesia

Email:md356@umkt.ac.id 
anger, helplessness, and fear of the patient's recurrence. A family member who suffer from mental disorders is a burden to the family, community, and health system (Newell \& Gournay, 2009), as well as the stigma in the community (Stuart, 2013). This phenomenon shows that not everyone is aware of the information and knowledge about mental disorders.

According to the survey results in Samarinda City, there are patients with mental disorders in the community who are shackled, separated from their families because of the stigma in the community. This stigma believes that people who are admitted to psychiatric hospitals must be people with mental disorders. As a result, many are reluctant to admit their family members who suffer from mental disorder to psychiatric hospitals. According to the findings of ten interviews with family members, six family members stated that they did not like, were confused, and embarrassed to have a family with mental disorders. They also stated that they were unable to take care of them. The study found that $52.6 \%$ of family perception toward family members with mental disorders were negative (Made et al. 2015). There are many things behind the consideration of families and communities to take care of family or community members who suffer from mental disorders, one of which is the lack of knowledge regarding mental disorders (Stuart \& Laraia, 2001). A person's lack of information might cause a decrease in family motivation in dealing with difficulties, leaving them unsure of what action to do (Notoadmojo, 2010).

Based on the phenomenon above, a team of lecturers from the Department of Mental Health, Nursing Science Study Program, Muhammadiyah University of East Kalimantan (UMKT) established a Community Mental Health Services and Research Clinic (Klinik Pelayanan dan Penelitian Keperawatan Jiwa Masyarakat or KP2KJM) as a solution for the problem of the lack of family and community knowledge toward someone with mental disorder and its management in society. Furthermore, it also addresses the community's needs which encompass not only issues related to mental disorders but also the concept of mental health itself. Thus, this clinic will be the initial treatment for patients with mental problems and the community with risk cases, as it is the only clinic in campus environment, and it will be a business owned by UMKT that will provide not only services but also research.

The clinic's product specifications include care services for healthy and risky community, mental disorder patients, as well as a community center for mental health research for lecturers and students. The availability of clinical space along with the equipment and human resources are required to generate this product. Besides, this clinic will undoubtedly become a training center for nurses from the Community Health Center (Puskesmas) and mental health cadres in Samarinda on a continuity basis, conducted by the lecturers with mental nursing specifications.

This clinic also has a vision and mission to achieve. Achieving Mental Health for the People of Samarinda in 2022 is the vision of this Community Mental Nursing Services and Research Clinic. Meanwhile, its missions are: 1) provide mental health nursing services; 2 ) improve the skills of mental health cadres; 3) develop researches on mental health nursing; and 4) become a model in developing mental health nursing services. As a result, the clinic has a duty that must be achieved to actualize a mentally health community not only in East Kalimantan but also in Indonesia.

In order to actualize the vision and mission above, the clinic activities will focus on counselling service programs for individuals, families, and communities to increase knowledge about mental disorders (Nambi, 2008), community mental health cadre training programs (KKJM) to increase the knowledge of early detection in the community, not only healthy cases, risks, and disorders (Keliat, 2011; Rosina, 2015), mental nursing modality therapy programs (Susana \& Hendarsih, 2012), home visits for community clients with the goal of monitoring the condition of clients who are taken care at home by their families, and determining the next nurse intervention (Keliat, 2011), as well as general health screenings for the community. Based on the aforementioned pehonomenon, the challenge faced by the people of Samarinda City is the lack of knowledge among family and community members in determining the state of mental disorders, as well as how to intervene and conduct mental disorder management.

\section{METHOD}

To fulfill the objectives of KP2KJM activities and to solve the problems and obstacles, the methods used are community education, consultation, and training. Some strategies for delivering education to the community include lectures, case discussions, demonstrations, and field trips. As a result of community education, there will be an improvement in knowledge, attitude, and practice related to mental health problems Consultation is done face-to-face between the client or family and the counsellor, starting with the identification and assessment of the client's problem and progressing to the action stage. Furthermore, one of the attempts in community empowerment is through training as an effort to improve community mental health by training its cadres (KKJM).

Descriptive research was conducted to determine the illustration of the level of knowledge. This research was conducted at the Community Mental Health 
Services and Research Clinic (KP2KJM) Muhammadiyah University of East Kalimantan from January to December 2018. The population in this study consists of all families of patients who visited the clinic, a total of 578 people. Meanwhile, the study's sample was taken by accidental sampling from 378 people who met the inclusion criteria, those who had never filled out a questionnaire. The questionnaire comprises of ten close-ended items on family knowledge of mental disorders, which is adopted from Suharsono (2017) and has been tested for validity and reliability. The instrument content validity test was conducted on 20 families who brought family members to the clinic and were declared valid with a $\mathrm{V}$ value for ten questions ranging from $0.75-0.84$, indicating that the knowledge level questionnaire was valid. Meanwhile, the realiability test for the level of knowledge obtained an $r$ value of 0.35 , indicating that the questionnaire's question items are reliable. Before filling out the questionnaire, the respondent was given Inform Consent followed by the submission of the questionnaire, which was then filled out by the respondent with the existing provisions. The analysis of the data used is univariate analysis. The knowledge category with the total score of 1-4 means poor, 5-7 is moderate, and $8-10$ is good. This study has passed the ethical test at the research Ethics Commission of Muhammadiyah University of East Kalimantan with a feasibility approval letter number 45/KEPK$\mathrm{UMKT} / \mathrm{I} / 2018$, where the research was conducted at the Community Mental Health Services and Research Clinic (KP2KJM) of Muhammadiyah University of East Kalimantan.

Furthermore, the clinic's supporting components are as follows: (1) Human resources to support the optimality of this clinic are UMKT lecturers with areas of competence and the focus of research being conducted out in Mental Nursing, Community, Nursing Management, psychology, sports, marketing, and information technology. In addition, this clinic is supported by counselors with partners from Jiwa Atma Husada Mahakam Samarinda Hospital and the professional organization of the Indonesian Mental Health Nurses Association (IPKJI) for the East Kalimantan Region and General Practitioners. (2) Standard Operating Procedures (SOP), the initial process begins with clinical preparation, providing tools that complement the facilities and infrastructure, then offer clients and clients' families, students and the general public about the promotion of the products or the prime ones from the clinic. Clients who come to the clinic are treated through several procedures, starting from understanding their problems: needs, gaps, causes, and then selecting the solutions for them. Actions and services are conducted in accordance with standard operating procedures (SOPs). (3) Marketing is needed to support the development of this clinical business unit. It is necessary to determine a marketing mix for market penetration, particularly in the designated target market, by boosting marketing activities with a promotional mix, as well as improving service quality. KP2KJM provides integrated services for customers to have a better brand identity. It is "One Stop Service," which implies that all patient care services can be carried out in this clinic. The method used is positioning statement (using the promotion staff to provide complete information to clients, families, and the community about the clinic); promotion strategy (maximizing the use of media, such as leaflets, posters, brochures, publications, banners, and electronic media, as well as social media); and developing strategy (collaborating with various health institutions). (4) Facilities and Infrastructure: the clinic, which is located at the UMKT campus, has five rooms with each function being a consultation room, therapy room, registration room, health promotion room, and client medical record room. The space provided by UMKT for a clinical room is an area of $15 \times 7 \mathrm{~m}^{2}$. The development of this space is to divide it into several rooms according to their functions, such as a front office where the recipients register the patients. Furthermore, arrangements are needed for a capacity of 10 clients and therapists in the treatment room, particularly the area for group activity therapy (TAK) for patients. The audio-visual facilities are used as the therapy tools for the clients. The consulation room between the mental clients and counselor must be very private. This clinic will create the community's mental health treatment system, which includes the mechanism, rules, and guidelines. UMKT will issue certificates for the trained mental health cadres.

\section{RESULT AND DISCUSSION}

\subsection{The first program: client consulting service program}

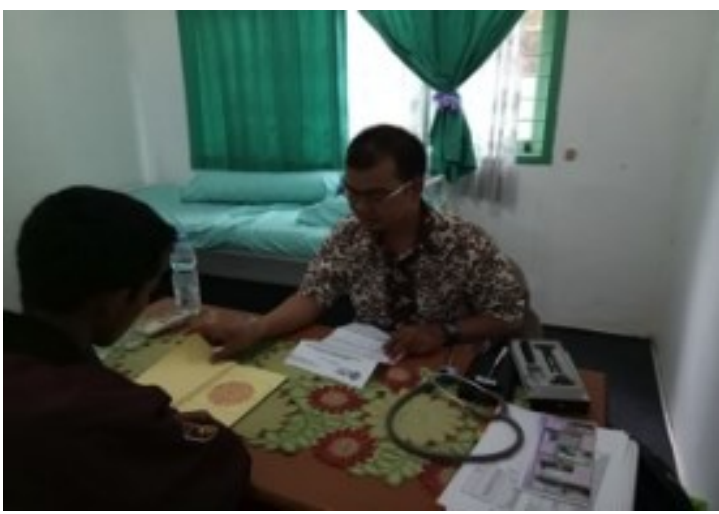

Figure 1. Consultation service

The clinic is open every weekday. The clinic is open 5 (five) days a week, from Monday to Friday, from 9 A.M. to 4 P.M. Central Indonesia Time. The 
counselor will be on duty according to the schedule, and if they are unable to be present, they will be substituted by another counselor. Therefore, the consulting service and therapy for the clients continue to be provided on a daily basis. During the consultation program, the counselor will select the most appropriate nursing modality therapy based on the patient's behavior. In the first year, 2017, the number of clients who consulted was 200, which then increased to 378 in 2018.

\subsection{The second program: modality therapy}

The mental nursing modality treatment service at $\mathrm{KP} 2 \mathrm{KJM}$ is a handling approach for clients that aims to change their behaviour from maladaptive to adaptive. Treatment modalities that are available in the clinic consist of individual therapy, group activity therapy, family therapy, occupational therapy, and energy channeling therapy. Each therapy has its own schedule. Individual therapy includes in the consultation between the client and the counselor. The therapist is the counselor in KP2KJM.

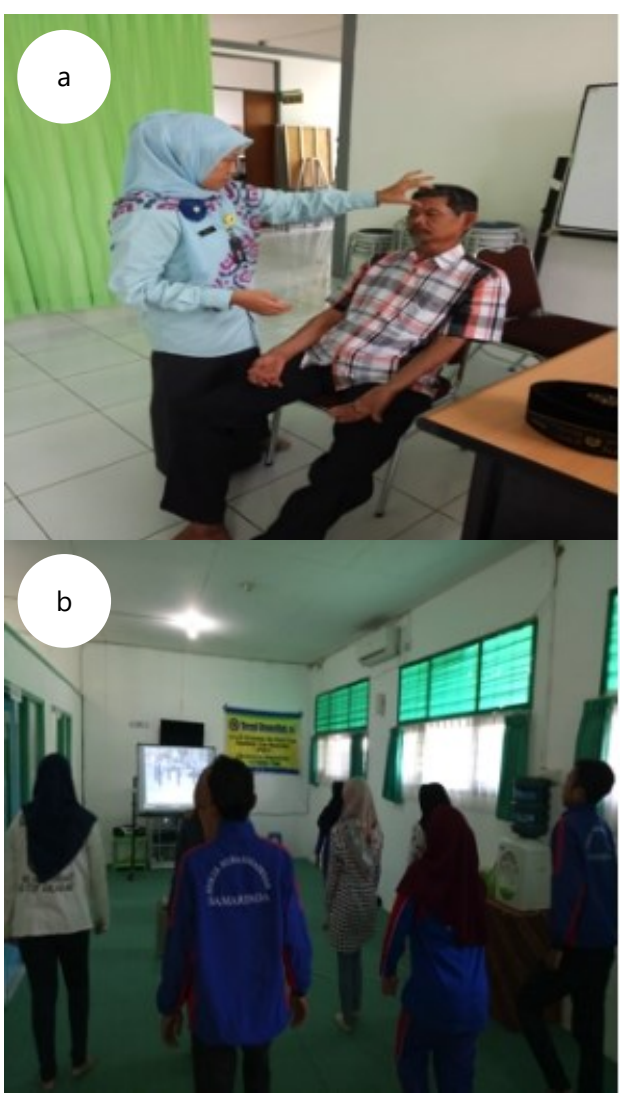

Figure 2. Therapy a) Individual therapy; b) Energy channeling therapy

\subsection{The third program: mental health cadre training (pelatihan kader kesehatan jiwa or kkj)}

One of KP2KJM's activities is training mental health cadres (KKJ) in partnership with the Community Health Center. The Primary Responsibilities of Mental Health Cadres are as follows: Implementing the Mental Health Wary Village (Desa Siaga Sehat Jiwa) program, 2) Detecting healthy families, families at risk for psychosocial problems, and families with mental disorders in the community, 3) Mobilizing individuals, families, and mentally healthy groups, groups at risk, and mental disorder groups to participate in mental health education, 4) Encouraging mental patients to attend mental health nursing modalities and rehabilitation, and 5) Conducting home visits. 6) Refer cases of psychosocial issues or mental disorders to Community Health Center or the UMKT Community Mental Nursing Services and Research Clinic

The recruitment mechanism for Mental Health Cadre (KKJ) is conducted in each working area of Juanda and Sempaja Community Health Center, where the KKJ will be responsible for 20 families. The nurses from the Community Health Center coordinate with the Head of the Neighborhood or community organization in their working area. Cadres who are interested must fill put a biodata form prepared by KP2KJM. The selected cadres must sign a declaration stating that they are willing to become mental health cadres and run the program. They are also required to undergo mental health cadre training. The number of cadres trained in the first year, 2017, was 50 people, and in the second year, 2018, was 100 people.

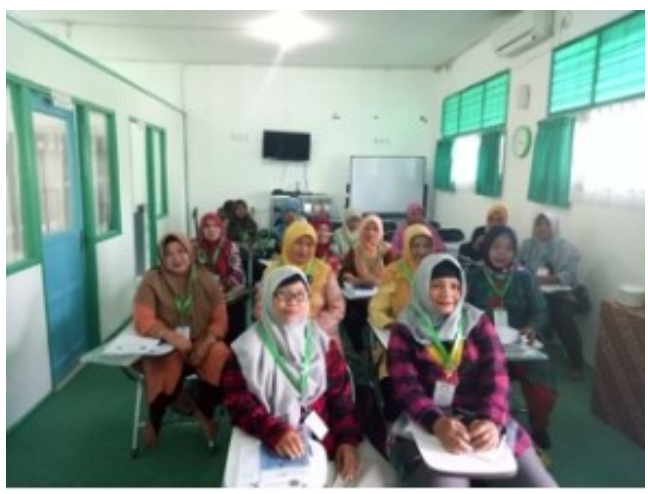

Figure 3. The training of mental health cadre (KKJ)

\subsection{The fourth program: client home visit}

Another program provided by the Community Mental Nursing Services and Research Clinic is home visits for clients who are taken care at home by their families. It aims to monitor the client's condition and determine the next nursing intervention. In order to advance and improve the quality and service of mental health in the community, it is necessary to have a cooperation between health workers and family members of clients who receive treatment, as well as inclusion in patient care programs both at home and in hospitals. It is significant to note that people with mental disorders are not usually treated in psychiatric hospitals.

In this case, the family plays an active part in optimizing the client to be independent and boosting their fulfillment of daily life. Providing information and education to families, as well as empowering families to care for patients at home is the purpose of home visit program. 


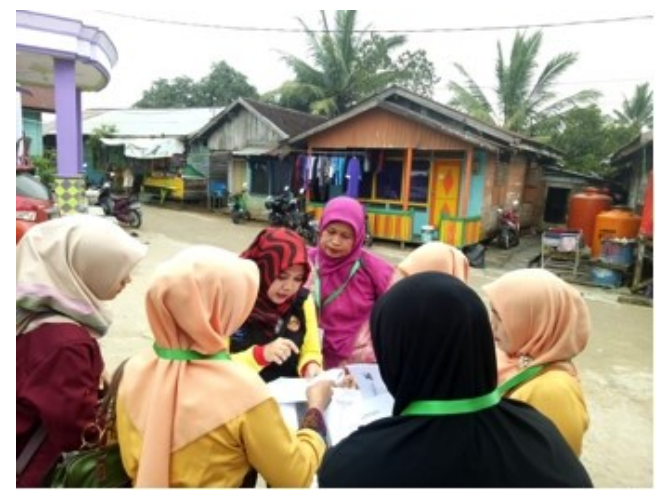

Figure 4. Home visit

\subsection{The fifth program: health education for mental health cadre and the community}

One of the components of community service is providing community education. Mental health education aims to make people have a healthy soul so they will avoid various forms of mental problems that will harm themselves and others. The following methods can be used to acquire a healthy soul. First, always think positively about whatever situation you are currently experiencing. Never think negatively of other people. Negative thoughts breed unfavorable prejudices, which can be fatal and impair your ability to think rationally. Once a month, health education for cadres and the community by delivering material on mental health is held at the Community Mental Nursing Services and Research Clinic (KP2KJM), with source persons from KP2KJM, the Health Community Center, Atma Husada Mahakam Samarinda Psychiatric Hospital, and the Indonesian Mental Health Nurses Association (IPKJI) of East Kalimantan.



Figure 5. Training of mental health cadre

According to Jacobalis (2000), age and gender are the factors that affect consumer perceptions of health services. The older a person is, the care that he or she demands are different than the younger (Maksum, et al, 2013). Similarly, when it comes to health care, elderly patients will demand courteous, quick, and better treatment. Mental health cadres play a critical part in this activity by informing the public that there are mental health services available on campus (Damayanti et al. 2019). One of the roles of mental health cadres is to improve, maintain, and preserve the community's mental health (Keliat, 2011). Thus, mental health cadres are in the forefront of dealing with and following up psychiatric disorders in the environment. Hence, the role of mental health cadres as community promoters is mostly twice as frequent as respondents' visits to mental clinics.

According to the findings of the study, there was a significant improvement in family knowledge after receiving health education and lectures from counselors, as well as mental health cadres. The moderate category increases from $35.7 \%$ to $46.03 \%$ after given the action, the good category increases from $23.02 \%$ to $33.86 \%$, while the poor category decreases from $41.27 \%$ to only $20.11 \%$. Knowledge is necessary to support attitudes and behavior, so it can be said that knowledge is a significant domain for the formation of action (Notoadmodjo, 2003). According to Tjiptono (2005), the major elements in delivering satisfactory service quality are the speed in providing services and timeliness used to serve patients, including dealing with patients' problems. According to Notoatmojo (2007), the amount of education, experience, culture, and economics all have an impact on a person's knowledge. Kurniawan and Sulistyarini (2016) have examined the association between giving training to assist cadres and developing expertise in dealing with mental health issues in the community. A research conducted by Rosiana et al. (2016) discovered that the results of mental health cadres training were the cadres' awareness of mental health problems, ability to explain mental health and how to handle it, ability to conduct early detection, and willingness to encourage the community to participate in counseling. Sutarjo et al. (2016) discovered an increase in cadre skills after receiving training.

According to Nurjannah (2001), officers should use the best possible amount of time when they are providing services, which is neither too lengthy nor too fast. Excessive length of examinations or services causes the patient to become bored oar saturated and considers the staff unprofessional. With a counselling service schedule for patients from Monday to Friday from 09.00 A.M. to 04.00 P.M. Central Indonesia Time, clients may access health services quickly and precisely. Mental health cadres aim to assist families in providing the care needed by the patients. The major thing that health cadres must do is to provide understanding in advance for families so they can accept the patient's condition. The openness of the family makes it easier for cadres and the Community Health Service to monitor the patient's condition. It is important to provide the appropriate information to the community so that the stigma that exists in the society can be erased and patients can receive the proper treatment (Putri et al., 2013). 


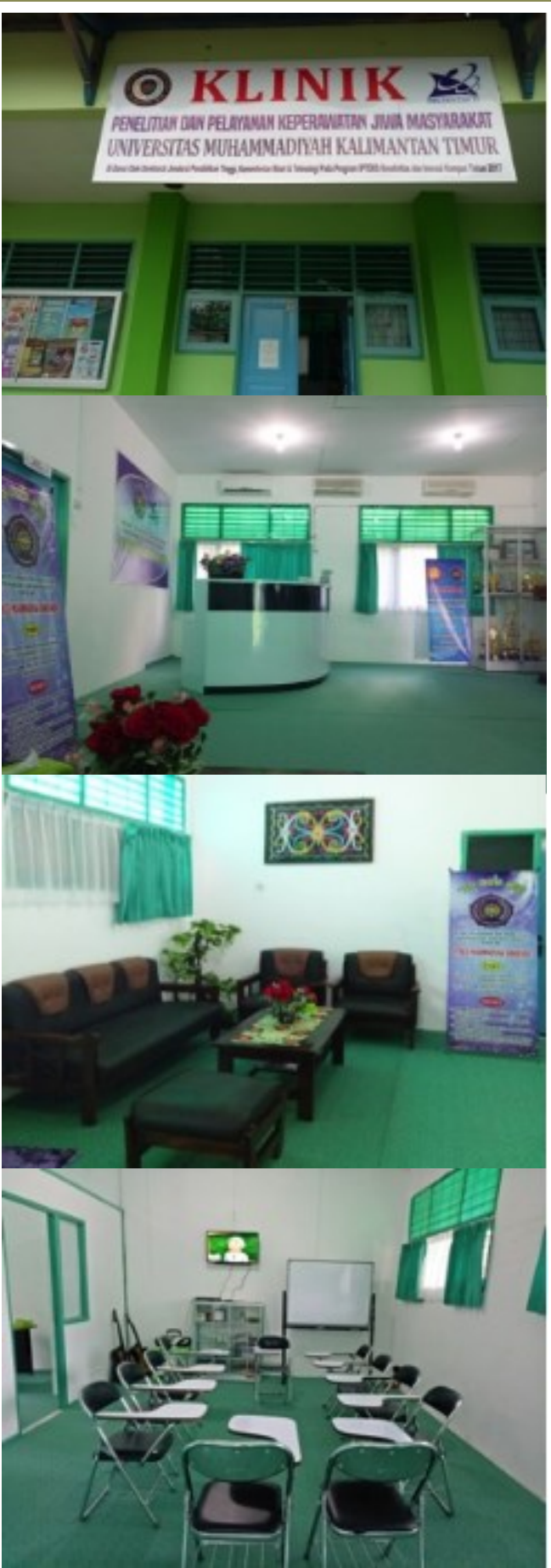

Figure 6. KP2KJM a) Signpost; b) Client's registration room; c) Client's waiting room; d) Modality therapy room

Home visit is a monthly activity done by mental health cadres. The visit aims to approach, collect data, and monitor the health of patients and their families, as well as to inquire about the family's abilities to care for patients with mental disorders. This is consistent with the triangulation theory, which states that the purpose of health cadres in visits is to gather current information about the patient's ability to cope with difficulties and family involvement in patient care at home (Nasir and Abdullah, 2011; Iswanti, et al, 2018). Home visits assist mental health cadres to identify health issues faced by the entire family. The information obtained is important for the Community Health Center. Family members who need to receive health services can be encouraged to use services provided by the Community Health Center (The Regulation of the Ministry of Health, 2016).

\section{Tabel 1. Characteristics of the respondents}

\begin{tabular}{|c|c|c|}
\hline Characteristic & $\begin{array}{l}\text { Amount } \\
(n=378)\end{array}$ & $\begin{array}{c}\text { Percentage } \\
(\%)\end{array}$ \\
\hline \multicolumn{3}{|l|}{ Gender } \\
\hline Male & 181 & 47.88 \\
\hline Female & 197 & 52.12 \\
\hline \multicolumn{3}{|l|}{ Age } \\
\hline $12-25$ years old & 86 & 22.75 \\
\hline $26-45$ years old & 132 & 34.92 \\
\hline $46-65$ years old & 160 & 42.33 \\
\hline \multicolumn{3}{|l|}{ Tertiary Education } \\
\hline Did not attend school & 4 & 1.06 \\
\hline Elementary School & 9 & 2.38 \\
\hline Junior High School & 32 & 8.47 \\
\hline Senior High School & 179 & 47.35 \\
\hline Diploma & 107 & 28.32 \\
\hline Bachelor & 47 & 12.43 \\
\hline \multicolumn{3}{|l|}{ Job } \\
\hline Student & 57 & 15.08 \\
\hline Civil servant & 87 & 23.02 \\
\hline Private sector employees & 92 & 24.34 \\
\hline Teacher/Lecturer & 8 & 2.12 \\
\hline Unemployed & 32 & 8.47 \\
\hline Housewife & 102 & 26.98 \\
\hline \multicolumn{3}{|l|}{ Frequency of Visits } \\
\hline Once & 118 & 31.22 \\
\hline Twice & 151 & 39.95 \\
\hline More than twice & 109 & 28.84 \\
\hline \multicolumn{3}{|l|}{ Source of Information } \\
\hline Family & 56 & 14.81 \\
\hline Mental Health Cadre & 128 & 33.86 \\
\hline Brochure & 77 & 20.37 \\
\hline Social Media & 24 & 6.35 \\
\hline Friend/Neighbor & 93 & 24.6 \\
\hline
\end{tabular}

Tabel 2. Level of family knowledge of mental disorders

\begin{tabular}{lcccc}
\hline \multicolumn{1}{c}{ Level } & \multicolumn{2}{c}{ Pre test } & \multicolumn{2}{c}{ Post test } \\
\cline { 2 - 5 } \multicolumn{1}{c}{ Knowledge } & Amount & \% & Amount & \% \\
\hline Good & 87 & 23.02 & 128 & 33.86 \\
Moderate & 135 & 35.71 & 174 & 46.03 \\
Poor & 156 & 41.27 & 76 & 20.11 \\
Total & $\mathbf{3 7 8}$ & $\mathbf{1 0 0}$ & $\mathbf{3 7 8}$ & $\mathbf{1 0 0}$ \\
\hline
\end{tabular}

\section{CONCLUSION}

Community Mental Health Services and Research Clinic (KP2KJM), as one of the business units for UMKT, has provided not only consulting services for clients in healthy conditions, at risk, and with mental disorders, but also modality therapy, mental health cadre training, client home visits, and health education for cadres and society. Based on the result of data analysis in this study, it is indicated that the level of family knowledge of mental disorders in Samarinda City is evenly moderate.

\section{ACKNOWLEDGMENT}

The Community Mental Health Services and Research Clinic (KP2KJM) Program Team, Muhammadiyah University of East Kalimantan, through the Multi-Year Community Service Grant for Campus Creativity and Innovation Program (Program Inovasi dan Kreatifitas Kampus or PPUPIK), The Research, Technology, and Higher Education (RISTEKDIKTI) of 2017-2019. 


\section{REFERENCES}

Badan penelitian dan Pengembangan Kesehatan (2007). Riset Kesehatan Dasar 2007. Kementrian Kesehatan Republik Indonesia. Jakarta.

Badan penelitian dan Pengembangan Kesehatan (2013). Riset Kesehatan Dasar 2013. Kementrian Kesehatan Republik Indonesia. Jakarta.

Damaiyanti, M., Fitriani, DR., Winarti, Y., et al (2019). Gambaran Kepuasan pasien Terhadap Pelayanan di Klinik Penelitian dan Pelayanan Keperawatan Jiwa Masyarakat (KP2KJM) UMKT. Prosiding Konferensi Nasional Keperawatan Kesehatan Jiwa (XVI). Vol 4(1). 49 - 56

Febrina, E. (2014). Rencana pemasaran klinik eksekutif RS. Hermina Depok dengan pendekatan Balance Scorecard. Jurnal Administrasi kebijakan Kesehatan, 1 (2).

Fortinash, K. M \& Worret, P. A.H (2004). Psychiatry Mental Health Nursing, $3^{\text {rd }}$ Edition. USA; Mosby

Iswanti, DI., Lestari, SP \& Hapsari, RD (2018). Peran Kader kesehatan Jiwa dalam melakukan Penanganan Gangguan Jiwa. Jurnal Ilmu Keperawatan Jiwa, Vol 1(1). 33-37

Jacobalis, S. (2000). Kumpulan Tulisan terpilih tentang Rumah Sakit Indonesia dalam Dinamika Sejarah Transformasi Globalisasi dan Krisis Nasional. Jakrta: IDi

Keliat, BA et al. (2011). Keperawatan kesehatan jiwa masyarakat CMHN (Basic course). Jakarta: EGC

Keliat, BA et al. (2011). Manajemen Keperawatan Psikososial \& Kader Kesehatan Jiwa CMHN (Intermediate Course). Jakarta: EGC

Keliat, B. A., Wiyono, A. P. \& Susanti, H. (2011). Manajemen Kasus Gangguan Jiwa. Jakarta; EGC.

Kessler, R.C et al. (2005). Lifetime prevalence and ageof-onset distributions of DSM-IV disorders in the National Cormobidity Survey Replication. Arch Gen Psychiatry, 62: 593-602. DOI: 10.1001/archpsyc.62.6.593

Kurniawan, Y \& Sulistyarini, I (2017). Komunitas Sehati (Sehat Jiwa dan Hati) sebagai Intervensi Kesehatan Mental Berbasis masyarakat. INSAN jurnal Psikologi dan Kesehatan Mental. 1(2): 112-124. DOI: 10.20473/jpkm.V1122016.112124

Made, N., Sulistiowati, D., Swedarma, K. E., Studi, P., Keperawatan, I., Kedokteran, F., \& Udayana, U. (2015). Pengaruh pelatihan kader terhadap kemampuan kader melakukan perawatan pasien gangguan jiwa di rumah.

Maksum W, Maidin A, Anggraini R. (2013). Gambaran tentang mutu pelayanan dokter berdasarkan persepsi pasien diInstalasi rawat jalan RS. UNHAS Kota Makasar. Fakultas Kesehatan Masyarakat. Universitas Hasanuddin, Makasar.

Mamnuah \& Nurjannah I. (2019). Kebutuhan Pasien Schizoprenia untuk mencapai Recovery di Komunitas. Prosiding Konfrensi Nasional
Keperawatan Kesehatn Jiwa (XVI). Vol 4(1), 5764.

Nambi, S (2008). Psychiatry for nurses. New Delhi. Jaypee Brothers.

Nasir, A \& Abdul M (2011). Dasar-dasar Keperawatan Jiwa. Jakrta: Salemba Medika

Newell, R \& Gournay, K. (2009). Mental Health Nurisng an Evidence Based Approach. Philadelphia, Churchill livingstone Elsevier. DOI: 10.1016/j.nepr.2009.02.005

Notoatmodjo, S. (2007). Promosi Kesehatan dan Ilmu Perilaku. Jakarta: Rineka Cipta

Notoatmodjo, S. (2010). Pendidikan Kesehatan dan Perilaku kesehatan. Jakarta: Rineka Cipta

Permenkes No. 44 Tahun 2016 Tentang Pedoman Manajemen Puskesma

Putri, R. A., Andrajati R, \& Bahtiar, A (2013). Perbandingan Efektivitas Konseling dan Poster Terhadap Kepatuhan dan Luaran Terapi pada Pasien Hipertensi. Jurnal Manajemen dan Pelayanan Farmasi. Vol 3(2) : 117-124

Rosiana, M,A., Himawan, R., \& Sukesih (2015). Pelatihan Kader Kesehatan Jiwa Desa Undaan Lor dengan cara deteksi dini dengan metode klarifikasi. The $2^{\text {nd }}$ University Research Coloquium.

Sadock, B. J., \& Sadock, V. A. (2007). Kaplan \& Sadock's synopsis of psychiatry: Behavioral sciences clinical psychiatry $\left(10^{\text {th }}\right.$ ed.). Philadelphia: Wolters Kluwer/Lippincott Williams \& Wilkins.

Santrock, J. W. (2007). A Topical Approach to Human life-Span Development. Mc-Graw-Hill, St. Louis, MO.

Stuart, G. W. (2013) Buku Saku Keperawatan Jiwa, ed 5. EGC, Jakarta.

Stuart \& Laraia (2001). Principle and Practice of Psychiatric Nursing. Edisi 8. St. Louis: Mosby Year Book.

Suharsono, (2016). Hubungan tingkat pengetahuan keluarga dengan keteraturan kunjungan berobat rawat jalan pada pasien skizofrenia di poli jiwa Rumah Sakit Jiwa Atma Husada Mahakam Samarinda. Skripsi, Universitas Muhammadiyah Kalimantan Timur

Susana, S.A., Hendarsih, S (2012). Terapi modalitas keperawatan kesehatan jiwa. Jakarta; EGC

Sutarjo, P., Prabandari, Y. S., \& Iravati, S. (2016). Pengaruh pelatihan community mental health nursing pada self efficacy dan keterampilan kader kesehatan jiwa, 67-72.

Tjiptono. F. (2005). Strategi Pemasaran, Edisi kedua. Yogyakarta: Andi Offset.

Varcarolis, E.M., Carson, V.B \& Shoemaker, N.C. (2006). Foundations of Psychiatric Mental health nursing, $5^{\text {th }}$ Edition, Saunders Elsevier, USA.

Yosep, I. (2013). Keperawatan Jiwa. Bandung: PT Refika Aditama 